Prace Literackie LX

Wrocław 2021

https://doi.org/10.19195/0079-4767.60.2

ELŻBIETA SZYNGIEL

ORCID: 0000-0002-2637-4153

Uniwersytet Wrocławski

\title{
Sposób kreowania postaci Juliusza Słowackiego w przestrzeni internetowej. Rekonesans
}

\section{Wstęp}

Romantyzm pozostaje intelektualnym fenomenem, który w dużym stopniu ukształtował polską kulturę w XIX i XX wieku. Chociaż mogłoby się wydawać, że po 1989 roku straci swoją siłę oddziaływania, jego nieustanna obecność we współczesnej literaturze i sztuce świadczy o tym, że romantyczne język, formy i motywy są nadal inspirujące i potrzebne bez względu na to, czy są impulsem dla współczesnych twórców, czy stają się przedmiotem polemik, często szyderczych. Tak rozumiana tradycja romantyczna jest stałym punktem odniesienia i w rezultacie - przedmiotem badań kulturo- i literaturoznawczych.

Jak zauważa Danuta Dąbrowska ${ }^{1}$, analizy te nadal jednak w przeważającej części koncentrują się na dziełach mieszczących się w kanonie szeroko rozumianej kultury wyższej. Chociaż zdaniem niektórych badaczy ${ }^{2}$ nawiązania do tradycji romantycznej w kulturze popularnej są zdecydowanie słabsze, w rzeczywistości wydaje się, że tradycja ta jest atrakcyjna zarówno dla twórców, jak i odbiorców dzieł zdefiniowanych jako „niższe”.

Kwestia przyczyn nieustannej atrakcyjności paradygmatu romantycznego dla kultury polskiej wydaje się niemożliwa do jednoznacznego rozstrzygnięcia. Jego atutem jest z pewnością fakt, że mieści w sobie pewną całościową narrację o świecie, obejmującą zarówno kwestie egzystencjalne dotyczące jednostki ludzkiej, jak i szerszą myśl społeczną, a ponadto refleksje estetyczne, epistemologiczne i historyczne.

${ }^{1}$ D. Dąbrowska, Wprowadzenie do tematu, [w:] Romantyzm $w$ kulturze popularnej, red. D. Dąbrowska, M. Litwin, Szczecin 2016, s. 7-10.

2 Por. A. Bagłajewski, Obecność romantyzmu, Lublin 2015, s. 8. 
W ostatnich latach ciekawym polem do eksploracji zjawiska zainteresowania romantyzmem jest internet. Niniejszy artykuł stanowi próbę analizy jednego z przejawów tego zainteresowania, mianowicie omówienia figury Juliusza Słowackiego i sposobu jej funkcjonowania w przestrzeni internetowej — zarówno w materialne graficznym, jak i filmowym.

Współcześnie Słowacki ma mocną pozycję w programie studiów polonistycznych i w kanonie lektur szkolnych, co prawdopodobnie leży u źródła faktu, że jego postać jest jedną z najczęściej eksponowanych postaci polskich poetów w internecie. W powszechnej świadomości zdaje się funkcjonować jednak przede wszystkim jako ikona polskiego romantyzmu. W tej roli usytuowany jest jednak zawsze na drugim miejscu, po Mickiewiczu. Należy przy tym podkreślić, że twórcy materiałów umieszczanych w sieci niewiele uwagi poświęcają twórczości poety, aspekty filozoficzne i estetyczne jego dzieł są niemal zupełnie pomijane. Prawdopodobnie wynika to z przekonania, że poezja Słowackiego jest stosunkowo wymagająca i często znajduje się poza zasięgiem poznawczym przeciętnego czytelnika.

Z wymienionych względów postać Słowackiego funkcjonuje w swoistej ambiwalencji $-\mathrm{z}$ jednej strony jako poeta będący obiektem nieustannego zainteresowania kręgów akademickich, wciąż na nowo analizowany i interpretowany, a w konsekwencji coraz bardziej hermetyczny, natomiast $\mathrm{z}$ drugiej - jako pewna figura o ściśle określonych cechach, replikowana w przestrzeni internetowej, wykreowana na podstawie stereotypów, traktowana w sposób nieco instrumentalny. $\mathrm{O}$ ile pierwsza $\mathrm{z}$ tych postaci zajmuje wiele miejsca na gruncie badawczym, o tyle druga nie została w wystarczającym stopniu rozpoznana.

\section{Juliusz Słowacki w internetowych materiałach graficznych}

Jednym z elementów przestrzeni internetowej, w której obecność Słowackiego zaznacza się najbardziej dobitnie, są memy. Samo pojęcie memu, chociaż już zakorzenione w polszczyźnie, nie doczekało się do tej pory jednoznacznej definicji. Najogólniej jest to termin używany na określenie elementu ikonicznego opatrzonego tekstem. Połączone rysunek i tekst mają w zamierzeniu wywołać efekt humorystyczny ${ }^{3}$. W szerszym ujęciu mem to gatunek wypowiedzi internetowej, odwołujący się do historii i kultury samego internetu, a w ich ramach — do elementów zrozumiałych dla przeciętnego użytkownika sieci ${ }^{4}$.

Najistotniejszą cechą konstytuującą memy jest ich replikowalność. Kryterium oceny takiego obrazka jest przede wszystkim to, w jakim stopniu staje się on popularny i powielany na portalach oraz w mediach społecznościowych. Oznacza

${ }^{3}$ D. Wężowicz-Ziółkowska, Jednostki pamięci kulturowej. Próba kulturoznawczej redefinicji i interpretacji hipotezy memetycznej, „Teksty z Ulicy. Zeszyt memetyczny” 2014, nr 15, s. 15-21.

${ }^{4}$ Ibidem. 
to, że do jego rozwoju niezbędna jest nie tylko aktywność jego twórcy, lecz także odbiorców, którzy rozpowszechniają go w wielu miejscach, dzięki czemu mem ma szansę dłużej i intensywniej funkcjonować w wirtualnej przestrzeni ${ }^{5}$.

W przestrzeni internetowej można odnaleźć zbiór memów, których bohaterem jest Juliusz Słowacki. Ich tematyka oscyluje przede wszystkim wokół rzekomego konfliktu, jaki istniał między poetą a Mickiewiczem. Najpowszechniejszy schemat konstrukcyjny tego rodzaju materiałów graficznych opiera się na wykorzystaniu wizerunków obu artystów - w wypadku Mickiewicza jest to dagerotyp z 1842 roku, natomiast Słowackiego - portret namalowany przez Juliusza Zubera ${ }^{6}$. Obaj mężczyźni przedstawieni są na ciemnym tle, często z dorysowanymi okularami. Ich podobizny są opatrzone krótkimi, szyderczymi, często wulgarnymi rymowankami, których przedmiotem jest twórczość lub osoba rywala. Memy z wizerunkiem Mickiewicza zawierają uwagi na temat poezji i stylu Słowackiego i odwrotnie - memy, na których widnieje Słowacki, odnoszą się do sztuki poetyckiej oraz sposobu bycia Mickiewicza. Tym samym artysta z Krzemieńca przedstawiany jest niejako z dwóch perspektyw — jako człowiek podający w wątpliwość talent swojego kolegi po piórze, a także jako obiekt krytyki tegoż kolegi.

Słowacki widniejący na memach opisuje poezję Mickiewicza między innymi w taki sposób: „Przedmiotem to nie jest/przydługich obrad,/Najgorszą powieścią/ Wallenrod Konrad”, a także: „Bursztynowy jest świerzop, gryka jak śnieg biała, Panieńskim jest rumieniec, zaś Mickiewicz pała” oraz: „Adamie, Adamie, piszesz, jakby ktoś stał nad Tobą z batem, następny raz jak chcesz zabłysnąć, to posyp się brokatem”. Z kolei Mickiewicz mówi o Słowackim następująco: „Do Słowackiego nie mam nic. Nawet szacunku". Również jego sztuka poetycka oceniana jest w negatywny sposób. Mickiewicz krytykuje ją na przykład tak: „My poeci wiemy, jak Kordian na nas działa/Większość, gdy to przeczytała,/to ino się śmiała".

Słowacki nie tylko źle mówi o koledze po piórze, lecz także wychwala samego siebie: „Mówią Julku — słabo ciśniesz,/mówią Adam znów prowadzi,/Lecz, mój drogi, ty zawiśniesz,/nawet Guślasz nie poradzi,/Twoja dusza wtem zawyje/ Obrzęd dziadów win nie zmyje,/Twych, co każdy zna ich parę/Kordian rządzi Ty cymbale".

Krótkie rymowanki widoczne w memach zawierają tytuły dzieł obu poetów (Konrad Wallenrod, Dziady, Kordian, Balladyna), ale odnoszą się też do rzekomych cech charakteru samych wieszczów. Mickiewicz wyśmiewa Słowackiego z powodu jego rzekomego zniewieścienia, słabości, tchórzostwa, egocentryzmu, nieumiejętności odnalezienia się wśród paryskiego towarzystwa.

Większość wierszy umieszczonych na memach jest bardzo prosta, ich autorzy operują potocznym językiem, wykorzystują nieskomplikowane rymy, często

5 M. Wójcicka, Mem internetowy jako multimodalny gatunek pamięci zbiorowej, Lublin 2019, s. 7.

${ }^{6}$ U. Makowska, Ananas vs jabłko, czyli sława popularna wieszczów, „Prace Filologiczne. Literaturoznawstwo" 2020, nr 10 (13), s. 175. 
są wulgarni. Ponadto rzadko podejmują grę z oryginalną twórczością wieszczów, nie nawiązują do niej za pośrednictwem konkretnych środków poetyckich.

Innym wycinkiem internetowej rzeczywistości, w której pojawia się Słowacki, są Facecje. Publikowane w serwisie Facebook Facecje stanowią odwołanie do swojej pierwotnej formy gatunkowej, jaką były krótkie, żartobliwe anegdoty przekazywane drogą ustną, które z czasem zaczęły przenikać do dzieł pisanych ${ }^{7}$.

Strona Facecji działa na Facebooku od listopada 2012 roku i od tego czasu zgromadziła ponad 81 tysięcy obserwatorów ${ }^{8}$, a każdy z opublikowanych materiałów otrzymuje od kilkuset do kilku tysięcy polubień. Główną domeną działalności jej autorów jest publikowanie spreparowanych rozmów między postaciami literackimi i historycznymi, które funkcjonują w kontekstach osadzonych we współczesności. W ten sposób twórcy starają się pokazać, w jaki sposób postacie te mogłyby korzystać z mediów społecznościowych:

Mamy więc do czynienia na przykład z Maryją, powiadamiającą społeczność o narodzeniu Jezusa za pomocą oferowanej przez Facebook funkcji ogłaszania ważnych wydarzeń z życia, z wykorzystaniem funkcjonalności facebookowej ankiety do wyboru najpiękniejszej z greckich bogiń, Filippidesem korzystającym z aplikacji Endomondo lub z Polską, która, z okazji święta odzyskania niepodległości zmienia „status związku” z ,to skomplikowane” na „wolna”.

Facecje w przeważającej większości mają formę zrzutów ekranu (zapisanych widoków ekranu komputera), na których widoczne są aktywności bohaterów i toczące się między nimi dialogi. W dialogach tych autorzy odwołują się do wydarzeń historycznych tudzież literackich, natomiast elementem ich fantazji są charaktery bohaterów oraz używany przez nich język. Rozmowy odbywają się w tak zwanych grupach, czyli charakterystycznych dla Facebooka kręgach zrzeszających ludzi o podobnych zainteresowaniach, stylu życia, obranych celach itp. Grupy umożliwiają nie tylko podjęcie dyskusji na konkretne tematy, lecz także nawiązanie nowych znajomości, wymianę opinii oraz uzyskanie pomocy wśród osób mających podobne problemy.

Postać Słowackiego pojawia się w Facecjach kilkakrotnie, po raz pierwszy w rozmowie dotyczącej pierwszego wydania Pana Tadeusza ${ }^{10}$. Facecja ma postać dyskusji na temat wspomnianego dzieła toczącej się między Mickiewiczem, Słowackim i Krasińskim. W odpowiedzi na status autora epopei narodowej, który z dumą obwieszcza publikację swojego poematu, Słowacki nie dość, że próbuje spostponować dzieło rywala, w obraźliwy sposób przekręcając jego tytuł (Pan

7 T. Michałowska Facecja, [w:] Stownik literatury staropolskiej, red. T. Michałowska, Wroclaw 2002, s. 243-244.

${ }^{8}$ Stan na lipiec 2021 roku.

9 B. Kulesza-Gulczyńska, Facecje na Facebooku — studium przypadku, „Forum Poetyki” 2016, nr 4-5, s. 72.

10 Żarty polonistyczne, Wieszcze narodowi i media społecznościowe, https://m.facebook.com/ ZartyPolonistyczne/photos/a.1388501598030309.1073741828.1380775075469628/165314409489 9390/?type $=3 \&$ source=48\&ref=bookmarks (dostęp: 17.07.2021). 
Sradeusz), to stara się usunąć go w cień, udzielając mu rady: „koleżko, idź być wieszczem gdzie indziej”.

Autor Balladyny jest przedstawiony jako antagonista Mickiewicza, artysta pogardzający dziełami rywala. W percepcji odbiorcy jest też postacią komiczną. Komizm ten jest rezultatem skontrastowania potocznego wyobrażenia na temat poety posługującego się pięknym językiem z jego rzekomymi wypowiedziami, których nie można określić mianem eleganckich czy wysublimowanych.

W kolejnej Facecji Słowacki podejmuje rozmowę z Fryderykiem Chopinem, który właśnie przybył do stolicy Francji i publicznie chwali się, w jaki sposób odnajduje się w środowisku polskiej emigracji ${ }^{11}$. Przyznaje się, że pożycza fortepian od Liszta, dzięki gruźlicy może korzystać z francuskiej opieki socjalnej i żyje w związku z kobietą, która go utrzymuje. Odpowiadają mu inni mieszkańcy Paryża - Mickiewicz, Norwid, Towiański, Sand i właśnie Słowacki. Ostatni z nich przedstawiony jest $w$ roli dandysa, a jednocześnie zblazowanego arystokraty, który pogardza innymi i chełpi się, że osiedlił się w tym miejscu, zanim stało się modne. Niezwykle dumny ze swojego stylu życia, daje do zrozumienia, że bywa w teatrach, jeździ eleganckim powozem i nie nękają go problemy materialne.

Słowacki jest w tej Facecji emanacją postawy prezentowanej przez mieszkańców dużych metropolii, krytykujących zbyt dużą ich zdaniem falę imigracji oraz związane z nią zjawiska - zakorkowane ulice (w tym przypadku powozami), obciążenia finansowe publicznego budżetu generowane przez przyjezdnych oraz artykułowaną przez nich krytykę obecnego miejsca zamieszkania przy jednoczesnej niechęci do wyjazdu. Poeta pisze wprost, że nowo przybyli „narzekają, że u nich było lepiej, ale podatki twardo płacą na swoich zadupiach". W analizowanym dialogu artysta nie jest postacią wzbudzającą sympatię, wręcz przeciwnie — budzi niechęć z powodu swojej postawy. Sprawia wrażenie zdegustowanego otaczającą go rzeczywistością, nieco neurotycznego, a jego zachowanie wyraźnie kontrastuje z zachowaniem Chopina zachwyconego życiem w stolicy Francji.

W innej interpretacji cała Facecja tworzy pewną nowoczesną w formie satyrę na życie ówczesnego polskiego środowiska emigracyjnego zmagającego się z trudnościami finansowymi, skonfliktowanego, bardzo zróżnicowanego pod względem społecznym i politycznym, które tutaj przedstawione jest jako nieco śmieszne, skoncentrowane na nieistotnych sprawach, zazdrosne i antypatyczne.

Trzecia Facecja przedstawia zamkniętą grupę Krypta na Wawelu ${ }^{12}$. Słowacki zamieszcza na niej komentarz inaugurujący nową rozmowę. Komentarz ma charakter powitania i powstaje po sprowadzeniu prochów artysty do Krakowa. W swojej wypowiedzi poeta prezentuje się zgoła odmiennie niż w poprzednich. Sprawia wrażenie zadowolonego z obecnego stanu rzeczy i miejsca, w którym

11 Facecje, Wreszcie Paryż, https://www.facebook.com/Facecje/photos/a.298817113557970/ 656815231091488 (dostęp: 17.07.2021).

12 Facecje, Krypta na Wawelu, https://www.facebook.com/Facecje/photos/a.29881711355 7970/753031404803203 (dostęp: 17.07.2021). 
się znalazł, jest rozbawiony, chce zintegrować się z pozostałymi mieszkańcami krypty i obiecuje, że zapewni im dobrą zabawę.

Wypowiedź Słowackiego, choć krótka, zawiera kilka gier językowych, będących odwołaniem do sytuacji, w której znajduje się artysta. Wspomina on o tym, że „od dzisiaj będzie spoczywał [z innymi] w pokoju” i „rozrusza tę grobową atmosferę". Ponadto chętnie używa emotikonów, które mają za zadanie zasugerować odbiorcom jego reakcje niewerbalne i zaskarbić mu ich sympatię.

Komentarz wieszcza spotyka się $\mathrm{z}$ różnymi reakcjami. Pochowane w kryptach wawelskich królowe Anna Jagiellonka, Anna Austriaczka oraz Barbara Zapolya są wyraźnie zainteresowane wieszczem („Panie poeto, pozdrowienia od dziewcząt z sąsiedniej krypty:* Austriaczka to się tak sypie na ten Twój sarkofag... Aż zmieniła fryzurę odpicowaną na zmartwychwstanie") ${ }^{13}$. Chopin deklaruje swoją przyjaźn podobnie jak - co warte podkreślenia - Mickiewicz, zachęcający do wspólnej gry w kości. Szczególnie ciekawa wydaje się wypowiedź Jana III Sobieskiego, który doradza poecie: „Rozłóż się wygodnie i patrz, co będą ci na górze robić z Twoim wizerunkiem i kto Cię będzie brał na sztandary. Przekręcisz się ze śmiechu"14, co jest znamienne w kontekście niniejszego artykułu.

Wizerunek Słowackiego w Facecjach budowany jest za pośrednictwem języka, którego używa wieszcz. Nie jest on w żaden sposób stylizowany ani archaizowany, nie kryje w sobie cytatów z jego dzieł poetyckich, wręcz przeciwnie pozornie niedbały, oparty na grach i aluzjach językowych, zawiera przekleństwa, słownictwo nieformalne, wiele wyrażeń używanych współcześnie, emotikonów i hasztagów, czyli znaków \#, z syntetycznym, ale jednocześnie skomplikowanym i żartobliwym opisem umożliwiającym selekcję treści.

Kreowanie postaci poety w Facecjach opiera się na zestawianiu dwóch nieprzystających do siebie porządków, z których jeden odwołuje się do powszechnie znanych, ważnych i uroczystych wydarzeń (sprowadzenie prochów poety do kraju, pierwsze wydanie epopei narodowej), natomiast drugi jest rezultatem opisanej tu konwencji językowej. Uzyskany efekt zaskakuje odbiorcę, który na skutek edukacji szkolnej utożsamia Słowackiego z poważnymi tematami i podniosłym stylem.

Omówione memy i facecje różnią się stylem, poziomem wyrafinowania i języka, ale wszystkie wspomniane materiały graficzne realizują przede wszystkim funkcję ludyczną, zastępując fragmenty starszych, bardziej poważnych narracji nowym systemem komunikowania się, który potrafi odczytać współczesny użytkownik internetu, jednak pod warunkiem posiadania pewnych kompetencji. Słowacki, który we wspomnianym systemie definiowany jest na nowo, zostaje w pewien sposób oswojony, często ośmieszony, ale jednocześnie staje się reprezentantem przeszłości opisanej na nowo.

13 Ibidem.

14 Ibidem. 


\section{Wizerunek Juliusza Słowackiego w filmach prezentowanych w serwisie YouTube}

W ostatnich latach na polskim gruncie dydaktyki polonistycznej coraz częściej wskazuje się na konieczność korzystania z treści udostępnianych na platformie YouTube ${ }^{15}$. Zarówno w przekonaniu teoretyków, jak i praktyków edukacji mogą one - odpowiednio omówione - być doskonałym materiałem uzupełniającym lekcje języka polskiego. YouTube umożliwia otwarcie niespotykanych do tej pory perspektyw w tym zakresie, dotarcie do zdecydowanie większej liczby widzów oraz współtworzenie przez nich odbieranych treści ${ }^{16}$.

Z możliwości, jakie niesie platforma YouTube, coraz chętniej korzystają twórcy różnego rodzaju kanałów edukacyjnych, w ramach których publikują filmy popularnonaukowe, często charakteryzujące się określoną konwencją.

Jednym z przykładów takiej przestrzeni jest kanał Historia bez Cenzury, istniejący na platformie od grudnia 2013 roku. Jego autorzy stworzyli do tej pory niemal 250 filmów. Wiele z nich osiągnęło setki tysięcy wyświetleń, a liczba ich stałych subskrybentów wynosi ponad 800 tysięcy ${ }^{17}$. Mają one formę krótkich materiałów paradokumentalnych poświęconych postaciom, wydarzeniom bądź zjawiskom historycznym. Opowiada o nich prowadzący - Wojciech Drewniak, filmowany w kostiumie i otoczeniu, które nasuwają przynajmniej pobieżne skojarzenia $\mathrm{z}$ tematem odcinka. Fragmenty jego wypowiedzi przeplatane są krótkimi sekwencjami zaczerpniętymi z filmów, teledysków muzycznych, a także obrazkami z komiksów czy memami internetowymi.

Historia bez cenzury jest programem, który można określić mianem popularnonaukowego, jednak zarówno dobór prezentowanych treści, jak i sposób ich przedstawiania konstytuują go jako koncept nieco odmienny niż pozostałe materiały edukacyjne o podobnym charakterze. Nieszablonowość Historii bez cenzury zasadza się na oryginalności omawianych tematów oraz narracji — przystępnej, humorystycznej, atrakcyjnej pod względem językowym i wizualnym. Innym elementem wyróżniającym kanał jest nieprzezroczystość przekazu, który z jednej strony można określić jako bardzo stronniczy, natomiast z drugiej — na wskroś współczesny, przez co często twórcy operują kontrastem między archaicznością tematu i nowoczesnością formy.

Trudno jednoznacznie określić kryterium, którym kierują się autorzy, wybierając bohaterów kolejnych odcinków. Z pewnością powodują nimi osobiste sympatie, ale często sięgają po życiorysy postaci mocno zakorzenionych w szkolnych

15 D. Żółtowski, YouTube w edukacji polonistycznej. Rekonesans, „Edukacja — Technika — Informatyka" 2020, nr 4, s. 319-324.

16 Por. H. Jenkins, Kultura konwergencji. Zderzenie starych i nowych mediów, Warszawa 2006.

17 Stan na lipiec 2021 roku. 
programach nauczania, co zdaje się dowodzić, że są świadomi edukacyjnej misji swojego kanału.

Być może Juliusz Słowacki właśnie z tego względu zasłużył na ich uwagę. Materiał na jego temat zatytułowany Dupek na Wawelu ${ }^{18}$ został opublikowany w serwisie You Tube 15 czerwca 2015 roku i obecnie ma ponad 1,4 mln wyświetleń ${ }^{19}$. We wstępie Drewniak prezentuje bohatera odcinka w następujący sposób:

Wszyscy znamy ten typ osoby — może i ma wielki talent, ale to, jakim jest burakiem, narcyzem, wymagającym poklasku i podziwiania swojej osoby, kompletnie ten talent przesłania. W piłce nożnej to Balotelli, w muzyce — Lars Ulrich, a w poezji — Juliusz Słowacki. [...] ulubiony poeta Piłsudskiego prywatnie był gościem, którego nikt z nas raczej by nie polubił — maminsynek, narcyz, hejter, a poza tym jeden z najwybitniejszych polskich poetów.

Ta krótka prezentacja jest nie tylko wprowadzeniem do życiorysu Słowackiego, lecz także sugestią dotyczącą tego, w jaki sposób postać zostanie zaprezentowana w dalszej części filmu. Jak wynika z przytoczonego cytatu, twórcy nie odmawiają Słowackiemu zdolności poetyckich, ale jednocześnie opisują go jako człowieka niesympatycznego, niecieszącego się uznaniem otoczenia, zazdrosnego o sukcesy bardziej utalentowanych rywali, niewzbudzającego zainteresowania kobiet, nieustannie pragnącego estetyzować swoje życie i podporządkowującego większość swoich aktywności temu pragnieniu.

Życiorys Słowackiego został w materiale przedstawiony w sposób chronologiczny. Drewniak rozpoczyna swoją opowieść od dzieciństwa artysty, wspomina o faktach z jego młodości: nauce na Uniwersytecie Wileńskim, pracy w Komisji Rządowej Przychodów i Skarbu. Następnie przechodzi do pracy poety na rzecz Rządu Narodowego w czasie powstania listopadowego, jego pobytu na emigracji i początków twórczości poetyckiej, podróży do Egiptu, relacji z Korą Pinard oraz Delfiną Potocką, uczestnictwa w Kole Sprawy Bożej. W zakończeniu mówi o ostatniej podróży wieszcza, jego próbach zaangażowania się w działalność niepodległościową w czasie Wiosny Ludów, śmierci i skromnym pogrzebie oraz złożeniu jego prochów na Wawelu. Nie ogranicza się przy tym do rejestracji faktów, ale wiele fragmentów życiorysu opatruje komentarzem, który stawia artystę w złym świetle i eksponuje jego wady. Przykładowo, prowadzący wspomina o złych relacjach Słowackiego z paryskim środowiskiem poetyckim, do których — jego zdaniem — w głównej mierze miał się przyczynić właśnie artysta z Krzemieńca. Zdaniem Drewniaka Słowacki krzywdzi młodziutką Korę, zaniedbuje sprawę wydania Beniowskiego, nie potrafi wzbudzić zainteresowania otoczenia.

Swoistą dominantą konstrukcyjną opowieści o Słowackim jest zestawienie różnych aspektów jego życiorysu z życiorysem Adama Mickiewicza, przy czym drugi z poetów jest uznany za zdecydowanie bardziej sympatycznego i utalentowanego. Konfrontowanie postaci realizowane jest w całym materiale. Drewniak

18 Dupekna Wawelu, https://www.youtube.com/watch?v=Dvs6codLz2U (dostęp: 17.07.2021).

19 Stan na 7 lipca 2021 roku. 
przywołuje opowieści o ich przyjściu na świat, porównuje ich pod kątem sympatii, jaką się cieszyli, i podkreśla, że Mickiewicz skrytykował poezję młodego Słowackiego, czego ten ostatni nie zauważył.

Stosunek autorów kanału do poetów uwidacznia się już w tytułach filmików. Materiał o Mickiewiczu zatytułowany został Romantyczny kozak. We wstępie Drewniak mówi, że:

Jego rymy przeszły do historii, bujał się z ziomkami i miał gdzieś policję, odbijał laski leszczom [...] kiedy jakiś typ go sfrajerzył i nasz bohater trafił do więzienia, nie wydał swojej ekipy [...] poza tym, nigdy się nie sprzedał, zawsze nawijał prosto z serca i najważniejszym był dla niego prosty przekaz.

Drewniak w ostatnim ujęciu filmu Dupek na Wawelu oddaje Słowackiemu sprawiedliwość, przyznając, że chociaż nie jest człowiekiem wzbudzającym jego szczególną sympatię, to jednak uznaje go za jednego z najwybitniejszych polskich poetów, który zdecydowanie zasłużył na pochówek w Krypcie Wieszczów Narodowych.

Twórcy filmów składających się na cykl „Historia bez Cenzury” na początku każdej swojej produkcji umieszczają zastrzeżenie, że zawiera ona kontrowersyjne skróty myślowe, tym samym dając do zrozumienia, że są świadomi dokonywanych uproszczeń i wprowadzają je do narracji w sposób przemyślany. Podobny zabieg stosują w wypadku filmu o Słowackim, w którym zdecydowali się na zaprezentowanie życiorysu poety przez pryzmat pewnych wyselekcjonowanych wydarzeń przy jednoczesnym pominięciu innych. Odcinają się przy tym od tradycji historycznoliterackiej, umieszczając obok wzmianek o pochodzeniu, wykształceniu, odbytych podróżach i kontaktach literackich informacje o wyglądzie zewnętrznym, relacjach z najbliższymi, związkach seksualnych, chorobach i śmierci artysty.

Drewniak i jego współpracownicy podejmują również starania o uwspółcześnienie przekazu. W swojej opowieści prowadzący używa leksyki i frazeologii potocznej. O kobietach Słowackiego mówi „laski”, jego pracę charakteryzuje jako „cholernie nudną”, zauważa, że „nigdy nie przegapił żadnej okazji, żeby trochę pogwiazdorzyć”, innych poetów określa mianem „ziomków”. Ponadto wzbogaca materiał o wiele odwołań do współczesnej kultury popularnej i jej bohaterów. Narracja prowadzącego przeplatana jest fragmentami polskich filmów fabularnych, których kwestie dialogowe tworzą komentarz do przedstawianej historii. Przytacza on również nazwiska znanych postaci, jak piłkarz Mario Balotelli, muzyk Lars Ulrich czy muzyk Jacek Kaczmarski. Wszystkie opisane tu zabiegi mają za zadanie zainteresować widza opowiadaną historią, utrwalić w jego świadomości pewne fakty i opinie.

Postać Juliusza Słowackiego pojawia się na platformie YouTube również w materiałach Grupy Filmowej Darwin. Jest to grono zawodowych aktorów, którzy od 2015 roku publikują w serwisie filmy o żartobliwym charakterze. Kanał 
uważany jest za jeden $\mathrm{z}$ najbardziej profesjonalnych w Polsce. W jego ramach twórcy zbudowali własne uniwersum, które zaludniają zarówno postacie historyczne, literackie, jak i wykreowane przez samych autorów.

Częścią wspomnianego uniwersum jest cykl „Wielkie Konflikty”. Składa się na niego kilkanaście filmów, które przedstawiają żartobliwe konfrontacje bohaterów znanych ze sztuki, literatury i historii. Grupa zrealizowała między innymi materiały przedstawiające utarczki między Edypem i Jokastą, Kainem i Ablem, Cezarem i Brutusem, Bogiem i Szatanem. Część z nich opiera się na powszechnie znanych faktach, natomiast inne w całości są fantazją autorów, jednak wszystkie, bez względu na koncept, na którym są oparte, wymagają od odbiorcy znajomości nie tylko pewnych faktów, lecz także współczesnego kodu kulturowego. Przykładowo, rozmowa między zrozpaczonymi Edypem i Jokastą staje się dla widza zupełnie nieczytelna, jeżeli nie zna on mitu o rodzie Labdakidów, natomiast oglądanie sporu między Wilkołakiem a Draculą staje się zdecydowanie ciekawszym i pełniejszym doświadczeniem w sytuacji, w której odbiorca potrafi rozpoznać wszystkie nawiązania do współczesnej popkultury i zna galerię literackich oraz filmowych potworów. Tym samym wszystkie konflikty są mocno zakorzenione w kulturze, a jednocześnie na wskroś oryginalne.

Jedną z części cyklu, która ma największą liczbę odsłon (ponad osiem milionów) ${ }^{20}$, jest konflikt między Mickiewiczem a Słowackim ${ }^{21}$. Jego akcja rozgrywa się w Tajnym Parku Poetów, po którym spaceruje uduchowiony Słowacki ubrany w luźne białe szaty. Po chwili zbliża się do niego Mickiewicz. Z treści rozmowy obu mężczyzn widz może wywnioskować, że Mickiewicz ma pretensje do Słowackiego. Powodem tych negatywnych uczuć ma być publiczna krytyka, którą uprawia jego powodowany zazdrością przeciwnik.

Autorzy filmu operują stereotypami na temat wieszczów, jakie funkcjonują w powszechnej świadomości. Także w tym materiale Słowacki przedstawiony jest jako człowiek skrajnie odmienny od Mickiewicza. Jawi się jako pretensjonalny poeta, przekonany, że każde napisane przezeń słowo jest warte zapamiętania. Nieustannie rozprawia o własnej twórczości, przypisując jej znaczenia i wartości, których nikt inny oprócz niego nie dostrzega. Według Mickiewicza „dopisuje on filozofię do swojego braku talentu".

Artysta sprawia wrażenie bardzo niesympatycznego, jest obdarzony wieloma negatywnymi cechami. Niemal obsesyjnie pragnie sławy i sugeruje, że posunie się do wszystkiego, aby ją osiągnąć. Ponadto brakuje mu odwagi. Obraża Mickiewicza przy każdej okazji, ale w bezpośredniej rozmowie nie potrafi znaleźć w sobie tyle męstwa, aby skonfrontować się z rywalem i wprost powiedzieć, co o nim myśli, wręcz przeciwnie — zachowuje się dwulicowo, podtrzymując z nim dobre kontakty.

20 Stan na lipiec 2021 roku.

${ }^{21}$ Mickiewicz vs Stowacki, https://www.youtube.com/watch?v=T2Cp14q1_ok (dostęp: 17.07.2021). 
O jego antypatycznym charakterze świadczy brak przychylności ze strony otoczenia. Słowacki przedstawiony jest jako człowiek samotny, pozbawiony nie tylko wielbicieli, lecz także bliskich. Zauważa to Mickiewicz, jednocześnie sugerując, że sam może liczyć na swoich „literatów z Wilna”, którzy w każdej chwili na jedno listowne wezwanie są gotowi przybyć mu z pomocą.

W materiale Mickiewicz vs Stowacki Grupa Filmowa Darwin wykorzystuje konwencję filmu dokumentalnego, przetwarzając ją w żartobliwy sposób. Obraz rozpoczyna się od ujęć Słowackiego, który spaceruje po parku, patrzy na wody jeziora, wącha kwiaty i szeptem recytuje poezję. Sprawia wrażenie człowieka pretensjonalnego i nieco śmiesznego. Prawdopodobnie zdecydował się wynająć grupę specjalistów, która poświęcony mu filmowy panegiryk, co tylko potwierdza prezentowane przez niego samouwielbienie.

Po chwili, wraz z pojawieniem się Mickiewicza, nastrój filmu się zmienia. Widz nie obserwuje już pogrążonego we własnych myślach artysty, lecz dwóch kłócących się mężczyzn. Sztuczna, estetyczna rzeczywistość wykreowana przez Słowackiego zmienia się w pozbawiony sztuczności spektakl.

Dokumentalna konwencja zasadza się na zastosowaniu kilku środków. W scenie początkowej twórcy umieszczają napisy mówiące o czasie i miejscu akcji. Materiał kręcony jest bez użycia statywu, a wszelkie gwałtowne ruchy kamery mają dać widzowi złudzenie obserwowania rzeczywistych wydarzeń uwiecznionych na taśmie filmowej. Ponadto w tle pojawiają się postacie odpowiedzialne za scenografię i oświetlenie. Aktorzy wcielający się w poetów w wybranych momentach decydują się na zburzenie czwartej ściany, zwracając się bezpośrednio do widzów. Mickiewicz wskazuje na Słowackiego, kpiąc: „oto artysta polski, proszę państwa!" i patrząc przy tym prosto w kamerę. Z kolei Słowacki, kierując swój wzrok w stronę potencjalnego widza, obraża swojego rywala, mówiąc: „wiecie, jaki to kretyn".

Wszystkie zabiegi uwypuklające gatunkowość filmu Słowacki vs Mickiewicz noszą znamiona pastiszowości i dzięki temu pogłębiają żartobliwy przekaz autorów. Jednocześnie jednak mają budować w odbiorcach wrażenie, że obcują oni z autentycznym materiałem i obserwują prawdziwy konflikt między artystami.

\section{Podsumowanie}

Zaprezentowana analiza wskazuje, że Słowacki istnieje w przestrzeni internetowej, a tym samym w powszechnej świadomości Polaków, jako postać o cechach negatywnych. Cechy te są uwypuklane przez zestawianie postaci Słowackiego i Mickiewicza, przy czym drugi z poetów jest w tym zestawieniu postacią zdecydowanie sympatyczniejszą, lepszą i ciekawszą.

Co znamienne, twórcy materiałów graficznych i filmowych, w których pojawia się Słowacki, nie wydają się zainteresowani rzeczywistym przebiegiem kon- 
fliktu między Słowackim i Mickiewiczem oraz tym, w jaki sposób relacje między poetami kształtowały się w ciągu lat. Zatargi między nimi ukazane są w uproszczeniu, a Słowacki jest w nich stroną opisywaną w sposób zdecydowanie bardziej pejoratywny. Niemal wszyscy przypisują mu zazdrość o literackie sukcesy rywala, często podkreślając przy tym niedostatki jego poezji oraz wady charakteru zazdrość, egzaltowanie, egotyzm, tchórzostwo.

Wypada tu wspomnieć, że konfrontowanie postaci Mickiewicza i Słowackiego oraz próby przyznania jednemu z nich palmy pierwszeństwa mają w Polsce długą tradycję. W 1899 roku „Kurier Warszawski” ogłosił ankietę, w której respondenci wybierali najważniejsze osiągnięcia Polaków w mijającym stuleciu. Ankieta została podzielona na wiele kategorii. W kategorii poezji zdecydowanie wygrał Mickiewicz, który uzyskał 312 głosów, wyprzedzając Słowackiego — ów otrzymał ich tylko 96. Za najważniejsze dzieło poetyckie Polacy uznali Pana Tadeusza oraz Dziady. Słowacki zwyciężył jedynie kategorii dzieła dramatycznego, uzyskując 66 głosów za Mazepe $e^{22}$.

Należy jednak podkreślić, że wspomniane badanie ankietowe nie zostało przeprowadzone wśród czytelników „Kuriera”, ale wśród naukowców i artystów, których opinia mogła znacznie odbiegać od opinii przeciętnych konsumentów kultury.

Na budowanie opozycji między wieszczami zwracał uwagę Tadeusz Boy-Żeleński, który pisał:

los tak splatał dzieje duchowe Mickiewicza i Słowackiego, że odlewanie olimpijskiego posągu jednego z nich odbywało się kosztem drugiego [...]. Aby wywyższyć i osłonić Mickiewicza, stworzono ów obraz Słowackiego jako małego, zarozumiałego i zawistnego rywala, niejako negatyw Mickiewicza, satelitę jego geniuszu. Taki wizerunek długo pokutował; i dziś jeszcze coś z niego straszy czasami $^{23}$.

Echem przekonania o wzajemnej niechęci poetów był też spór o miejsce pochówku prochów Słowackiego. Część środowisk artystycznych, społecznych i religijnych uważała, że nie powinien on spoczywać obok „trupów w koronach [...] i tego trupa, co był wielki" ${ }^{24}$, ponieważ sam swoją wielkością mu nie dorównywał.

Przez lata opinia o antagonizmie wieszczów i procesy zestawiania oraz porównywania ich z sobą utrwaliły się w kulturze. Należy przy tym zaznaczyć, że dyskutantów opowiadających się po jednej ze stron rzadko interesuje wartość estetyczna lub filozoficzna dzieł obu poetów, a także relacje historyczne dotyczące ich związków emocjonalnych i towarzyskich; istotniejszy jest sam konflikt, który często przybiera formę przypominającą współzawodnictwo sportowe ${ }^{25}$.

22 Por. Konkurs stulecia, „Kurier Warszawski” 1900, nr 1.

23 T. Boy-Żeleński, Brązownicy, Warszawa 1930, s. 18.

24 J. Żuławski, Trzeci, „Młodość” 1899, nr 6, s. 145. „Trup tego, co był wielki” to Mickiewicz.

25 M. Nesteruk, O co Stowacki spierat się z Mickiewiczem? „Rocznik Towarzystwa Literackiego im. Adama Mickiewicza" 34, 1999, s. 111. 
Pewien konkretny sposób kreowania Słowackiego w przestrzeni wirtualnej nie jest całkowicie niezgodny z rzeczywistością, a niektóre stereotypy dotyczące jego postaci miały swoje źródło w zachowaniach samego poety, opisanych w korespondencji i wspomnieniach $z$ epoki. $Z$ dokumentów wiemy, że rzeczywiście był artystą spragnionym sławy, a także niechętnym znacznej części środowiska emigracyjnego, które otwarcie krytykował w swoich listach. Część drobnych przywar poety z czasem, na skutek różnych okoliczności zewnętrznych, została wyolbrzymiona, a sam wieszcz — umieszczony w pewnej konkretnej roli w panteonie artystów polskich.

Upraszczanie i trywializowanie jego postaci w ostatnich latach zdecydowanie się zintensyfikowało. Twórcy i odbiorcy materiałów internetowych czerpią z mód widocznych na rynku wydawniczym, na którym pojawia się coraz więcej publikacji skoncentrowanych nie na dziełach, lecz na osobach twórców i przedstawiających ich życiorysy w możliwie najbardziej sensacyjny sposób, często bez koniecznego umocowania $\mathrm{w}$ faktach ${ }^{26}$.

Tego rodzaju dążenia — zarówno w publikacjach książkowych, jak i internetowych - mają w zamyśle uatrakcyjnić przedstawianych bohaterów, którzy $\mathrm{w}$ tym ujęciu stają się swoistymi celebrytami, uczestnikami medialnego show ${ }^{27}$.

Ze względu na obszerność materiału niemożliwe jest przeanalizowanie wszystkich przejawów obecności Słowackiego w przestrzeni internetowej, jednak już po pobieżnym jej zbadaniu można zrekonstruować pewną figurę wieszcza obecną w świadomości jej użytkowników. Analiza tego rodzaju materiału wydaje się o tyle zasadna, że w sposób bardzo intensywny kształtuje on pamięć zbiorową, będąc jednocześnie przykładem pozainstytucjonalnej formy przekazu wiedzy historycznej i literackiej. Ten ,zbiór wyobrażeń członków zbiorowości o jej przeszłości, o zaludniających ją postaciach i minionych wydarzeniach, jakie w niej zaszły"28, który Barbara Szacka definiuje jako przejaw wspomnianej pamięci zbiorowej, niezwykle silnie oddziałuje na kolejne pokolenia, stanowiąc jednocześnie dowód na reprezentowane przez nie wartości i potrzeby ${ }^{29}$.

\section{BIBLIOGRAFIA}

Adamczewska I., Pisarz w mediach masowych, czyli autentyzm jako literacki chwyt (auto)promocyjny, ,Teksty Drugie” 2012, nr 6.

Bagłajewski A., Obecność romantyzmu, Lublin 2015.

${ }^{26}$ Por. S. Koper, Nieznane losy autorów lektur szkolnych. Wstydliwe tajemnice mistrzów pióra, Warszawa 2020; idem, Sekretne życie autorów lektur szkolnych. Nie tacy święci jak ich maluja, Warszawa 2020.

27 I. Adamczewska, Pisarz w mediach masowych, czyli autentyzm jako literacki chwyt (auto) promocyjny, ,Teksty Drugie” 2012, nr 6, s. 301.

28 B. Szacka, Czas przeszly: pamięć-mit, Warszawa 2006, s. 19.

29 M. Wójcicka, op. cit., s. 13. 
Bąk M., Twórczy lęk Słowackiego. Antagonizm wieszczów po latach, Katowice 2013.

Bodusz M., Juliusz Stowacki - poeta popularny, [w:] Juliusz Stowacki w kontekstach kulturowych dawnych $i$ wspótczesnych, red. E. Dąbrowska, I. Jokiel, Opole 2012.

Boy-Żeleński T., Brązownicy, Warszawa 1930.

Dąbrowska D., Wprowadzenie do tematu, [w:] Romantyzm w kulturze popularnej, red. D. Dąbrowska, M. Litwin, Szczecin 2016.

Jenkins H., Kultura konwergencji. Zderzenie starych i nowych mediów, Warszawa 2006.

Konkurs stulecia, „Kurier Warszawski” 1900, nr 1.

Koper S., Nieznane losy autorów lektur szkolnych. Wstydliwe tajemnice mistrzów pióra, Warszawa 2020.

Koper S., Sekretne życie autorów lektur szkolnych. Nie tacy święci, jak ich malują, Warszawa 2020.

Kulesza-Gulczyńska B., Facecje na Facebooku — studium przypadku, „Forum Poetyki” 2016, nr 4-5.

Makowska U., Ananas vs jabtko, czyli stawa popularna wieszczów, „Prace Filologiczne. Literaturoznawstwo" 2020, nr 10 (13).

Michałowska T., Facecja, [w:] Stownik literatury staropolskiej, red. T. Michałowska, Wrocław 2002.

Nesteruk M., O co Stowacki spierat się z Mickiewiczem? „Rocznik Towarzystwa Literackiego im. Adama Mickiewicza" 34, 1999.

Szacka B., Czas przeszty: pamięć-mit, Warszawa 2006.

Wężowicz-Ziółkowska D., Jednostki pamięci kulturowej. Próba kulturoznawczej redefinicji i interpretacji hipotezy memetycznej, „Teksty z Ulicy. Zeszyt memetyczny” 2014, nr 15.

Wójcicka M., Mem internetowy jako multimodalny gatunek pamięci zbiorowej, Lublin 2019.

Żółtowski D., YouTube w edukacji polonistycznej. Rekonesans, „Edukacja — Technika — Informatyka" 2020.

Żuławski J., Trzeci, „Młodość” 1899, nr 6.

\section{The way of creating Juliusz Slowacki's image online. Reconnaissance}

Summary

The article concerns the ways of creating Juliusz Słowacki's image online. The problem is discussed based on graphic material (memes, facetiae) and film material (productions in the series "Historia bez cenzury" [History without censorship], "Wielkie konflikty" [Great conflicts]). The authoress briefly discusses the viability of the Romantic paradigm in contemporary Polish culture and the reminiscence of this presence, which is key in the image of the poet shaped by authors and internet users. Next, the authoress characterises the artist based on the collected research material.

In most cases, Słowacki is presented as a negative character - a cowardly, pretentious, conceited man, jealous of the poetic talent of his fellow writers. He is often confronted with Adam Mickiewicz, a character depicted much more positively.

Summing up, the authoress considers the reasons for this type of simplification of the image of the Polish bard on the internet, and concludes that it is the result of building a schematic image of the world based on stereotypes; this image then begins to function in the collective memory of society.

Keywords: Juliusz Słowacki, the antagonism of prophets, Romanticism, Romanticism in popular culture, popular culture 